\title{
THE ESTIMATION OF CALCIUM IN URINE* BY FLAME PHOTOMETRY, WITH A NOTE ON THE ESTIMATION OF SODIUM AND POTASSIUM
}

\author{
BY \\ W. P. U. JACKSON AND L. IRWIN \\ From the Endocrine/Metabolic Laboratories, Department of Medicine, University of Cape Town, \\ South Africa
}

(RECEIVED FOR PUBLICATION OCTOBER 20, 1956)

\begin{abstract}
Many methods for calcium estimation by flame spectrophotometry have been described. Investigations of biological material have dealt chiefly with plasma (Baker, 1955; Chen and Toribara, 1953 ; Denson, 1954; Kingsley and Schaffert, 1953 ; Llaurado, 1954 ; MacIntyre, 1954 ; Mosher et al., 1951 ; Rothe and Sapirstein, 1955 ; Winer and Kuhns, 1953 ; Zak et al., 1953), with application to urine in some cases (Chen and Toribara, 1953 ; Kingsley and Schaffert, 1953; Rothe and Sapirstein, 1955 ; Severinghaus and Ferebee, 1950 ; Winer and Kuhns, 1953). The removal of interfering substances has been accomplished by precipitating calcium by oxalate (Chen and Toribara, 1953 ; Kingsley and Schaffert, 1953 ; Llaurado,
\end{abstract} 1954) or diammonium hydrogen phosphate (Mosher et al., 1951) and by cation exchange columns (Brabson and Wilhide, 1954 ; Denson, 1954). Direct readings have been employed, using synthetic standards to compensate for interfering elements (Baker, 1955; Kingsley and Schaffert, 1953 ; MacIntyre, 1954 ; Winer and Kuhns, 1953) or determining sodium and potassium before calcium (Chen and Toribara, 1953 ; Severinghaus and Ferrebee, 1950). Radiation buffers (West et al., 1950) and selfstandardization methods (Rothe and Sapirstein, 1955) have also been used.

Most of these methods are either very time consuming or may be used only for specimens such as plasma and tissue which have a narrow range of variation. It is difficult to adapt one method to urine which will compensate for the widely varying composition found in both normal and pathological specimens.

Rothe and Sapirstein (1955) survey the difficulties and demerits of the various published

* Applicable also to food and faecal extracts methods. In this laboratory these have been found to be as follows.

(1) Oxalate precipitation and ashing before flame photometry: this method is too lengthy, and also suffers from the risk of loss of calcium in the early manœuvres.

(2) Oxalate precipitation and washing is also lengthy, and it was not possible to recover the standard additions.

(3) Direct reading on a Beckman photometer against a synthetic standard was not suitable for the wide range of cation concentrations found in urine.

(4) Direct reading with self-standardization was not a reproducible method, nor were calcium readings proportionately enhanced on addition of sodium, potassium, and phosphorus within the necessary range.

(5) The determination of sodium and potassium beforehand and then adjusting to standard concentration is lengthy and subject to anion interference.

(6) An absorption column to eliminate anions is suitable for a narrow range of sodium and potassium, but with urine the cation interference is too great.

(7) After whatever method of preparation the acetylene/oxygen flame has been found to give too high a background for work with calcium (up to $50 \%$ at slit width 0.05 ).

The principal interfering cation is sodium. which enhances calcium readings in any dilution at both $422.7 \mathrm{~m} \mu$ and $554 \mathrm{~m} \mu$ even when very narrow slit widths are employed. The enhancement due to sodium alone had been found to increase proportionately with increasing calcium concentration, but not in the presence of phosphate (Fig. 1). 


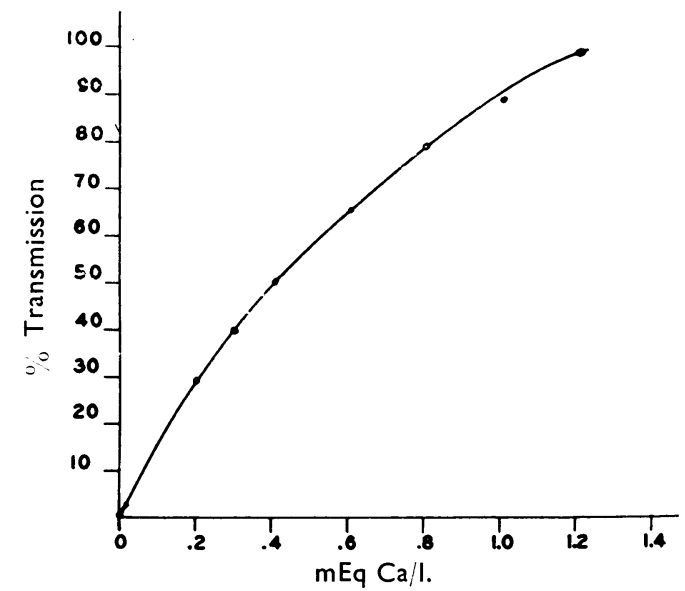

FIG. 1.-Interference of sodium and phosphate on calcium curve. Standard calcium $+10 \mathrm{mEq} /$. Na $+3 \mathrm{mEq} / 1$. $\mathrm{PO}_{4}$. Slit width $0 \cdot 13$. Wavelength, 554. Sensitivity full, counter-clockwise.

\section{Method}

The method presented here eliminates anion interference by passing the urine specimen through a cation exchange column similar in construction to that of Denson (1954). Its original feature is the separation of sodium and potassium by differential elution with $\mathrm{N}$ hydrochloric acid, before the final elution of the calcium, which may then be read directly.

Absorption Column.-The column adopted is similar to that of Denson (1954) using "dowex" 50 (Dow Chemicals), 50-100 mesh, as the exchange medium. A hollow glass tube about $18 \mathrm{~cm}$. long, diameter $0.6 \mathrm{~cm}$., narrowed at one end and connected to a funnel at the other, is plugged with glass wool and filled with resin by pouring in a water suspension of this to a height of about $12.5 \mathrm{~cm}$. The rate of flow is approximately $0.6-1.0 \mathrm{ml} . / \mathrm{min}$.

This column is prepared for use by (1) adding $25 \mathrm{ml}$. $6 \mathrm{~N} \mathrm{HCl}$; (2) washing down the sides with two, approximately $10 \mathrm{ml}$., quantities of distilled water after the liquid level is below the funnel opening; (3) putting through about $35 \mathrm{ml}$. of distilled water until the eluate is nearly neutral to litmus. This is done several times before using.

Samples of urine are acidified $(1 \mathrm{ml}$. concentrated hydrochloric acid to $100 \mathrm{ml}$. urine) and filtered. Then $10 \mathrm{ml}$. of the filtrate (or more or less for abnormally low or high calcium-containing specimens) is added to the absorption column, followed by two separate washings of $10 \mathrm{ml}$. distilled water. This can be qualitatively tested for calcium to check the absorption of cations.

Sodium and potassium are then eluted with $\mathrm{N}$ hydrochloric acid by collecting exactly $20 \mathrm{ml}$. of eluate. (Calcium will start to come out immediately after $20 \mathrm{ml}$.) Calcium is next obtained by adding im- mediately $3 \mathrm{~N}$ hydrochloric acid to the column and collecting approximately $35 \mathrm{ml}$. eluate in a $100 \mathrm{ml}$. volumetric flask.

This calcium-containing eluate is diluted to volume with distilled water and analysed directly using standards* ranking from 0 to $1.2 \mathrm{mEq} / 1$. calcium prepared in approximately $\mathrm{N}$ hydrochloric acid.

It has been found necessary to wash the column with $10 \mathrm{ml}$. of distilled water, followed by $10 \mathrm{ml}$. of $3 \mathrm{~N}$ ammonia, then $10 \mathrm{ml}$. of water again, after elution of every specimen and before the resin is regenerated with acid. This procedure has been adopted to get rid of chromogens and amphoteric substances which otherwise clogged the column. Used in this way the columns will last a long time, until eventually, with shrinkage, the rate of flow becomes greatly diminished and the tube must be repacked.

Instrument.-A Beckman model DU spectrophotometer with flame and photomultiplier attachment was used. A hydrogen/oxygen flame was used when high sensitivity could not be obtained with acetylene/ oxygen.

Settings.-These are set out in Table I.

TABLE I

CONDITIONS FOR ESTIMATION OF CALCIUM. POTASSIUM, AND SODIUM

\begin{tabular}{|c|c|c|c|c|c|}
\hline & $\begin{array}{l}\text { Wave- } \\
\text { length } \\
(\mathrm{m} \mu)\end{array}$ & $\begin{array}{l}\text { Photo- } \\
\text { tube }\end{array}$ & $\begin{array}{c}\text { Slit } \\
\text { Width }\end{array}$ & $\begin{array}{l}\text { Urine } \\
\text { Dilution }\end{array}$ & $\begin{array}{l}\text { Photo- } \\
\text { muitiplier } \\
\text { Setting }\end{array}$ \\
\hline Sodium & 589 & $\begin{array}{l}\text { Photo- } \\
\text { multiplier }\end{array}$ & & 1,100 & 2 \\
\hline Potassium & 789 & Red & 0.06 & $\begin{array}{c}1,100 \\
\text { sodium } \\
\text { buffer }\end{array}$ & - \\
\hline Calcium & 554 & $\begin{array}{l}\text { Photo- } \\
\text { multiplier }\end{array}$ & 0.06 & $\begin{array}{c}110 \\
\text { (variable) }\end{array}$ & 5 \\
\hline
\end{tabular}

(1) The wavelength $554 \mathrm{~m}$ ". was found to be most sensitive. Those at 422.7 and $622 \mathrm{~m}{ }^{\prime \prime}$ were tried, but the wide slit widths necessary at these wavelengths increased the interfering light from other elements.

(2) Sensitivity is determined by turning on the fuel at position 5 on the photomultiplier tube with the selector switch at 0.1 and the sensitivity knob about one turn from the counter-clockwise limit. The zero suppression switch may be left off or turned to position 1 .

(3) A slit width of $0.06 \mathrm{~mm}$. gave the most reproducible results. Smaller slit widths could be used, but the readings deviated too widely.

Procedure.-After the instrument has been allowed to warm up the fuel cylinders are turned on, and working pressure gauges are turned to $25 \mathrm{lb} . / \mathrm{sq}$. in. for oxygen and to 5-10 lb./sq. in. for hydrogen. The oxygen regulator on the flame photometer is screwed in until the pressure reads 6-7 lb./sq. in., then hydrogen to $2 \mathrm{lb}$./sq. in. The burner is lit and the hydrogen

*Standards prepared from calcium carbonate by usual methods. 
pressure adjusted to $4 \frac{1}{2} \mathrm{lb}$./sq. in. The fuel needle is adjusted to give a flame $2-2 \frac{1}{2}$ in. in height with the solution spraying.

The slit width, selector switch, and wavelength are then set. The shutter being closed, the meter needle is zeroed with the dark current knob, the shutter then opened, and the percentage transmission given by the solution blank is read. This should be below $10 \%$; if greater either the flame background is too high or extraneous light is leaking through the cell.

With the shutter open, the blank is set to $0 \%$ transmission with dark current adjustment, and the highest standard to $100 \%$ transmission with the sensitivity knob. The percentage transmission given by the lower range of standards is read at this setting and a standard curve established. Subsequently it is unnecessary to read more than two or three standards to check the instrument.

Unknown solutions are read after rechecking the blank and standard settings, and results taken from the standard graph.

A beaker of distilled water is sprayed through to clear the burner before closing off the hydrogen and then the oxygen tank.

\section{Results}

Standard Curve.-Fig. 2 shows the standard calcium curve obtained with the hydrogen/oxygen flame.

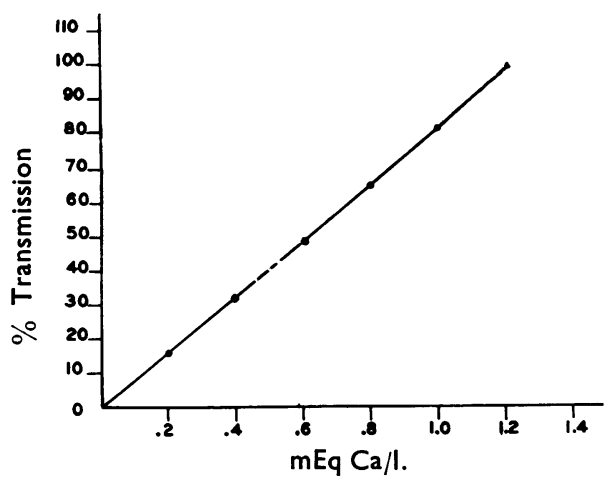

Fig. 2.-Standard calcium curve.

Recoveries.-Recovery experiments were satisfactory for $2,5,10$, and $25 \mathrm{ml}$. quantities of urine (Table II). The urine specimens were obtained from normal individuals and from patients with abnormally high and abnormally low urine calcium levels. The small amount of sodium and potassium which may remain in the calcium eluate does not interfere at such dilutions. Synthetic solutions with high and low calcium content and containing large amounts of sodium, potassium, magnesium, and phosphate were also found to give good recovery values (Table III) after being passed through the column. Magnesium added to urine before it is passed through the column made no difference to the recoveries obtained (Table IV).

TABLE II

RECOVERIES OF CALCIUM ADDED TO URINE

\begin{tabular}{|c|c|c|c|c|c|}
\hline $\begin{array}{c}\text { Condition } \\
\text { of Person } \\
\text { Providing } \\
\text { Urine }\end{array}$ & $\begin{array}{c}\text { Initial } \\
\text { Calcium } \\
(\mathrm{mEq} / .)\end{array}$ & $\begin{array}{c}\text { Urine } \\
\text { Passed } \\
\text { through } \\
\text { Column } \\
\text { (ml.) }\end{array}$ & $\begin{array}{l}\text { Calcium } \\
\text { After } \\
\text { Addition } \\
\text { (mEq } 1 .)\end{array}$ & $\underset{\text { Found }}{\text { Calcium }}$ & $\begin{array}{c}\% \\
\text { Recovery }\end{array}$ \\
\hline $\begin{array}{l}\text { Osteo- } \\
\text { porosis }\end{array}$ & $2 \cdot 7$ & $\begin{array}{l}10 \\
10\end{array}$ & $\begin{array}{l}47 \\
6 \cdot 7\end{array}$ & $\begin{array}{l}4 \cdot 7 \\
6 \cdot 7\end{array}$ & $\begin{array}{l}100 \\
100\end{array}$ \\
\hline $\begin{array}{c}\text { Hypopara- } \\
\text { thyroid }\end{array}$ & 0.56 & $\begin{array}{l}25 \\
25 \\
10 \\
25 \\
10\end{array}$ & $\begin{array}{l}1 \cdot 76 \\
2 \cdot 56 \\
8 \cdot 56 \\
096 \\
37\end{array}$ & $\begin{array}{l}1 \cdot 76 \\
2.64 \\
8 \cdot 7 \\
1 \cdot 00 \\
3.6\end{array}$ & $\begin{array}{r}100 \\
103 \\
102 \\
104 \\
97\end{array}$ \\
\hline $\begin{array}{l}\text { Sarcoid- } \\
\text { osis }\end{array}$ & $7 \cdot 4$ & 5 & 9.4 & $9 \cdot 8$ & 104 \\
\hline Normal & $8 \cdot 1$ & $\begin{array}{r}10 \\
10 \\
10 \\
10 \\
10 \\
5\end{array}$ & $\begin{array}{l}9.1 \\
11 \cdot 1 \\
13.1 \\
11.4 \\
13.4 \\
20.4\end{array}$ & $\begin{array}{r}9.4 \\
11.6 \\
133 \\
11.3 \\
13.1 \\
20.0\end{array}$ & $\begin{array}{r}103 \\
104 \\
101 \\
99 \\
98 \\
98\end{array}$ \\
\hline Normal & $\begin{array}{r}4 \cdot 5 \\
10 \cdot 7 \\
10 \cdot 6 \\
4 \cdot 0\end{array}$ & $\begin{array}{r}2 \\
10 \\
6 \\
10\end{array}$ & $\begin{array}{c}9 \cdot 5 \\
11 \cdot 7 \\
1227 \\
6.0\end{array}$ & $\begin{array}{c}9 \cdot 5 \\
11 \cdot 6 \\
12 \cdot 30 \\
6 \cdot 1\end{array}$ & $\begin{array}{r}100 \\
99 \\
100 \\
102\end{array}$ \\
\hline Pregnant & 1.75 & $\begin{array}{l}5 \\
2 \\
2\end{array}$ & $\begin{array}{r}375 \\
21 \cdot 75 \\
36 \cdot 75\end{array}$ & $\begin{array}{l}3 \cdot 80 \\
225 \\
370\end{array}$ & $\begin{array}{l}101 \\
104 \\
101\end{array}$ \\
\hline
\end{tabular}

TABLE III

RECOVERIES OF CALCIUM ADDED TO SYNTHETIC STANDARDS

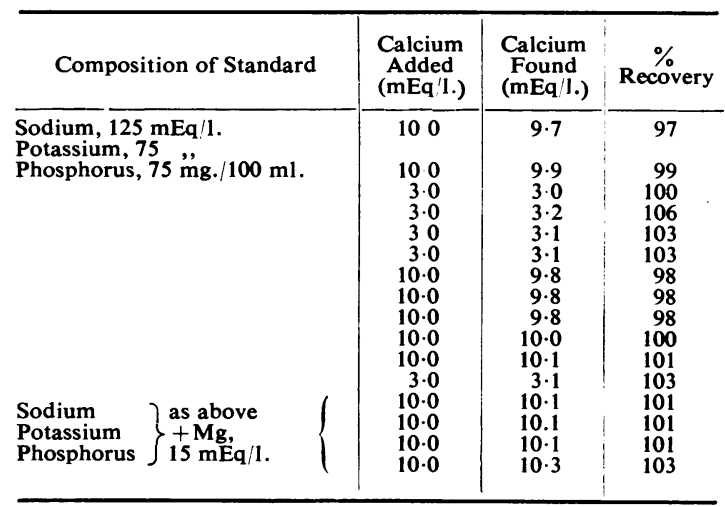

TABLE IV

RECOVERIES OF CALCIUM ADDED TO URINE CONTAINING ADDITIONAL MAGNESIUM

\begin{tabular}{c|c|c|c|c|c}
\hline $\begin{array}{c}\text { Calcium } \\
\text { (ml.) }\end{array}$ & $\begin{array}{c}\text { Initial } \\
\text { Calcium } \\
\text { (through } \\
\text { Column }\end{array}$ & $\begin{array}{c}\text { Magnesium } \\
\text { Added } \\
\text { (mEq/1.) }\end{array}$ & $\begin{array}{c}\text { Calcium } \\
\text { after } \\
\text { Addition } \\
\text { (mEq/1.) }\end{array}$ & $\begin{array}{c}\text { Calcium } \\
\text { Found } \\
\text { (mEq/1.) }\end{array}$ & $\begin{array}{c}\% \\
\text { Recovery }\end{array}$ \\
\hline 5 & 7.4 & - & 9.4 & 9.8 & 104 \\
5 & 7.4 & 2.0 & 9.4 & 9.8 & 104 \\
5 & 7.4 & 5.0 & 9.4 & 9.8 & 104 \\
25 & 0.44 & 5.0 & 0.44 & 0.44 & 100 \\
\hline
\end{tabular}




\section{Discussion}

Analyses of calcium by this method can be made in about 90 minutes. Any number of specimens may be prepared simultaneously, depending only on the number of available columns.

Accurate results can be obtained within a wide range of sodium, potassium, and phosphate concentrations, since these interfering elements are removed. The method can be used satisfactorily on ashed extracts of faeces and food, as in metabolic balance work.

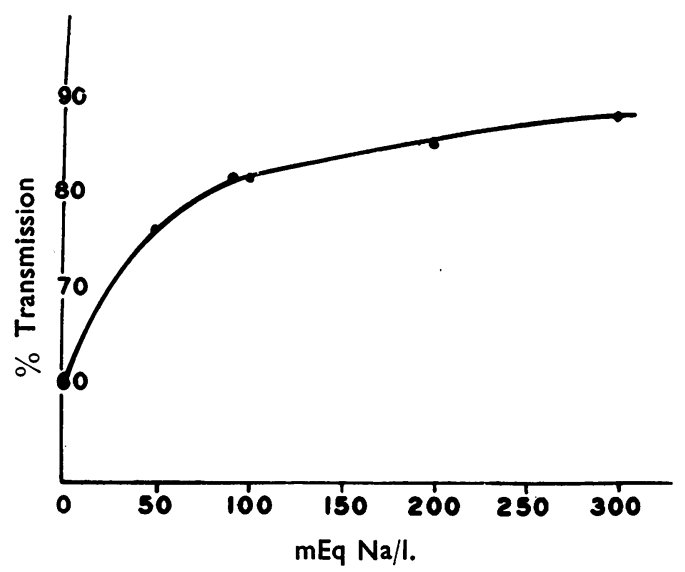

FIG. 3.-Interference of sodium on potassium estimation using a constant concentration of $K(0.5 \mathrm{mEq} / 1$.$) and varying amounts$ of $\mathrm{Na}$. Note that at a $\mathrm{Na}$ concentration of $100 \mathrm{mEq} / \mathrm{l}$. the curve has virtually reached a plateau.
Determination of Sodium and Potassium

Sodium and potassium may be estimated in the unmodified urine. We have, however, found it necessary to determine potassium in a sodium buffer (containing $100 \mathrm{mEq} / \mathrm{l}$. of sodium) to eliminate the effects of sodium interference (Fig. 3 ), in view of the wide variations of both elements in urine. Table I shows the conditions under which the various ions are estimated.

We are pleased to thank Professor G. C. Linder, Dr. A. Antonis, Mr. H. Crumb, and Dr. L. Anstey for their help with technical details. We acknowledge the $\stackrel{\circ}{\circ}$ assistance of the Council for Scientific and Industrial $\vec{P}$ Research, whose technician one of us (L. I.) was, and of the University of Cape Town Staff Research Fund for a grant for expenses.

REFERENCES Baker, G. L., and Johnson, L. H. (1954). Analyt. Chem., 26, 465. 응 Brabson, J. A., and Wilhide, W. D. (1954). Analyt. Chem., 26, 1060. Chen, P. S., and Toribara, T. Y. (1953). Ibid., 25, 1642.

Denson, J. R. (1954). J. biol. Chem., 209, 233.

Kapuscinski, V., Moss, N., Zak, B., and Boyle, A. J. (1952). Amer. J. clin. Path., 22, 687

Kingsley, G. R., and Schaffert, R. P. (1953). Analyt. Chem., 2F, 1738 .

Llaurado, J. G. (1954). J. clin. Path., 7, 110.

MacIntyre, I. (1954). Biochem. J., 56, XIII (proceedings).

Mosher, R. E., Bird, E. J., and Boyle, A. J. (1950). Analyt. Chem., 22,715

- Itano, M., Boyle, A. J., Myers, G. B., and Iseri, L. T. (195 Amer. $J$ clin Path $21,75$.

Rothe, C. F., and Sapirstein, L. A. (1955). Ibid., 25, 1076.

Severinghaus, J. W., and Ferrebee, J. W. (1950). J. biol. Chence 187, 621 .

Smith, R. G., Craig, P., Bird, E. J., Boyle, A. J., Iseri, L. T., Jacobson̆ S. D., and Myers, G. B. (1950). Amer. J. clin. Path., 20, 263. West, P. W., Folse, P., and Montgomery, D. (1950). Analyt. Chem., 22, 667 .

Winer, A. D., and Kuhns, D. M. (1953). Amer. J. clin. Path., 23, 1259.

Zak, B., Mosher, R. E., and Boyle, A. J. (1953). Ibid., 23, 60. 